\title{
PENINGKATAN KEMAMPUAN PEMECAHAN MASALAH, KOMUNIKASI \\ DAN KONSEP DIRI MATEMATIK SISWA SMP MELALUI PEMBELAJARAN KONTEKSTUAL BERBANTUAN GEOGEBRA
}

\author{
Yanti \\ Email : yantichang761@yahoo.com \\ Guru SMPK Tri Mulia Bandung
}

\begin{abstract}
The goal of this research is to know the achievement and the enhancement of mathematical skills, such as problem solving (KPM), communication (KKM) and self-concept (KDM) between the students who experience the contextual teaching learning with geogebra $(P K G)$ and those who receive the expository teaching and learning $(P E)$. This is a quasi-experimental research that applies the non-equivalent group control design. The research population is the eight's grade students in one of the junior high school in Bandung. The group samples in the research are chosen from two classes. The research instruments include the test of KPM, KKM, and KDM. It also applies the data tabulation which uses the t-test, t'-test. The research then reveals the following results: (1) The students who received the PKG are better in the achievement of KPM, compared to those who experienced the $P E$, (2) The students who received the PKG are not better in the achievement of KKM, compared to those who experienced the PE, (3) The students who received the PKG are not better in the enhancement of KPM and KKM, compared to those who experienced the PE, (4) The KDM achievement of the students who experienced the PKG is indifferent to those who received the PE.
\end{abstract}

Key words: Contextual teaching and learning with geogebra, mathematical problem solving skill, mathematical communication skill, mathematical self-concept skill

ABSTRAK

Penelitian ini bertujuan untuk mengetahui pencapaian dan peningkatan kemampuan pemecahan masalah (KPM), komunikasi (KKM) dan konsep diri (KDM) matematis antara siswa yang memperoleh pembelajaran kontekstual berbantuan geogebra (PKG) sebagai kelas eksperimen dengan siswa yang memperoleh pembelajaran ekspositori (PE) sebagai kelas kontrol. Jenis penelitian adalah kuasi eksperimen dengan desain kelompok kontrol non-ekivalen. Populasi penelitian adalah seluruh siswa kelas VIII salah satu SMP swasta di kota Bandung dengan sampel dipilih dengan cara kelompok. Instrumen penelitian meliputi tes PKM, KKM dan KDM. Pengolahan data menggunakan uji t, uji t'. Hasil penelitian: (1) Pencapaian KPM siswa yang memperoleh PKG lebih baik daripada siswa yang memperoleh PE, (2) Pencapaian KKM siswa yang memperoleh PKG tidak lebih baik dari siswa yang memperoleh PE, (3) Peningkatan KPM dan KKM siswa yang memperoleh PKG tidak lebih baik dari siswa yang memperoleh PE, (4) Pencapaian KDM siswa yang memperoleh PKG tidak berbeda dengan siswa yang memperoleh PE.

Kata kunci: Pembelajaran kontekstual berbantuan geogebra, kemampuan pemecahan masalah matematis, kemampuan komunikasi matematis, kemampuan konsep diri matematis

\section{PENDAHULUAN}

Latar Belakang; Kemampuan pemecahan masalah dan komunikasi matematis dikalangan siswa sekolah menengah di Indonesia masih sangat rendah.Hal ini berarti tujuan pendidikan matematika yang tercantum di dalam kurikulum matematika sekolah menengah di Indonesia dan Permendiknas No.22 (Depdiknas, 2006) belumlah tercapai. Hasil penilaian dari TIMSS pada tahun 1999, 2002 dan 2011 menempatkan Indonesia pada peringkat yang masih rendah dengan perolehan skor yang jauh di bawah rerata internasional (TIMSS, 2011). Lindawati (2010) dan Multahadah (2015) dalam penelitiannya secara berturutturut menemukan bahwa rerata skor hasil pretes kemampuan komunikasi matematis adalah $20,88 \%$ dan rerata skor hasil pretes kemampuan pemecahan masalah adalah $14,32 \%$ terhadap skor ideal.

Berdasarkan tes diagnostik yang dilakukan tersebut ditegaskan bahwa rendahnya kemampuan pemecahan masalah siswa disebabkan oleh faktor kesulitan dalam memahami kalimat-kalimat dalam soal, siswa 
tidak dapat membedakan informasi yang diketahui dan permintaan soal, mengalami kesulitan dalam menggunakan pengetahuan yang diketahui, lemahnya strategi dalam mengubah kalimat cerita menjadi kalimat metematika, dan menggunakan cara-cara yang berbeda-beda dalam merencanakan penyelesaian suatu masalah. Salah satu faktor lainnya adalah model penyajian materi pelajaran (Ruseffendi, 2006:13).

Sumarmo (2012) mengungkapkan bahwa untuk memaksimalkan proses dan hasil belajar matematika, guru perlu mendorong siswa terlibat secara aktif dalam diskusi, siswa dibimbing untuk bisa bertanya serta menjawab pertanyaan, berpikir kritis, menjelaskan setiap jawaban yang diberikan, serta mengajukan alasan untuk setiap jawaban yang diajukan. Pembelajaran yang diberikan menekankan pada penggunaan strategi diskusi, baik diskusi dalam kelompok kecil maupun diskusi dalam kelas secara keseluruhan.Karakteristik-karakteristik pembelajaran tersebut terangkum dalam suatu model pembelajaran kontekstual.

Salah satu karakteristik pembelajaran kontekstual adalah menggunakan multi media dan sumber belajar, diantaranya adalah perangkat lunak matematika, dalam hal ini adalah GeoGebra yang mampu mengoptimalkan proses konstruksi pengetahuan baru secara bermakna melalui pengalaman nyata sehingga mengalami suatu proses penemuan sertamemberikan peluang luas kepada kita untuk memanfaatkannya dalam meningkatkan efektivitas pembelajaran.

Selain kemampuan kognitif, terdapat kemampuan afektif yang mempengaruhi prestasi belajar siswa di sekolah. Apabila siswa memandang dirinya sebagai orang yang tidak mempunyai cukup kemampuan untuk melakukan suatu tugas, maka seluruh perilakunya akan menunjukkan ketidakmampuannya tersebut. Pandangan guru maupun siswa lain juga akan mempengaruhi pandangan siswa tersebut, tanggapan positif akan membantu siswa bersikap positif terhadap dirinya sendiri sehingga dapat mempengaruhi prestasi belajar.

Rumusan masalah; Adapun rumusan masalah dalam penelitian ini adalah: (1) Apakah pencapaian dan peningkatan kemampuan pemecahan masalah dan komunikasi matematis siswa yang mengikuti Pembelajaran Kontekstual berbantuan Geogebra lebih baik dari siswa yang memperoleh Pembelajaran Ekspositori?; dan (2) Apakah terdapat perbedaan konsep diri matematis siswa yang memperoleh pembelajaran kontekstual berbantuan geogebra dengan siswa yang memperoleh pembelajaran ekspositori?

Tujuan penelitian; Tujuan penelitian ini adalah untuk mengetahui: (1) Pencapaian dan peningkatan kemampuan pemecahan masalah dan komunikasi matematis antara siswa yang memperoleh Pembelajaran Kontekstual berbantuan Geogebra dengan siswa yang memperoleh Pembelajaran Ekspositori; dan (2) Perbedaan konsep diri matematis antara siswa yang memperoleh pembelajaran kontekstual berbantuan geogebra dengan siswa yang memperoleh pembelajaran ekspositori.

Pemecahan Masalah Matematis; Proses pemecahan masalah matematik berbeda dengan proses menyelesaikan soal matematika (Sumarmo, 2012). Suatu tugas matematik digolongkan sebagai masalah matematik apabila tidak dapat segera diperoleh cara menyelesaikannya namun harus melalui beberapa kegiatan lainnya yang relevan. Suatu masalah untuk individu atau siswa pada jenjang sekolah tertentu belum tentu merupakan masalah untuk individu atau siswa jenjang sekolah yang lebih tinggi.Polya (1957) merinci kegiatan pemecahan masalah sebagai berikut: kegiatan memahami masalah, kegiatan merencanakan atau merancang strategi pemecahan masalah, kegiatan melaksanakan perhitungan, kegiatan memeriksa kembali kebenaran hasil atau 
solusi.

Komunikasi Matematis; Sumarmo (2012) menjelaskan kegiatan yang tergolong pada komunikasi matematis diantaranya adalah: (a) menyatakan suatu situasi, gambar, diagram, atau benda nyata ke dalam bahasa, symbol, idea, atau model matematis, (b) menjelaskan idea, situasi, dan relasi matematika secara lisan atau tulisan; (c) mendengarkan, berdiskusi dan menulis tentang matematika; (d) membaca dengan pemahaman suatu representasi matematika tertulis; (e) mengungkapkan kembali suatu uraian atau paragraf matematika dalam bahasa sendiri.

Konsep Diri; Menurut Marsh (Githua \& Mwangi, 2003), konsep diri matematis adalah persepsi diri dari seorang siswa mengenai perasaan pribadinya tentang keahlian dan kemampuan matematika, kemampuan penalaran matematika, kesenangan dan ketertarikan dalam bermatematika.Hamachek, Rotherham, dan Swayze (Jiang, 2000) menyatakan bahwa ciri-ciri siswa yang memiliki konsep diri positif adalah memandang dirinya penting, mampu menunjukkan kinerja yang baik pada saat tertekan sekalipun dan menggunakan pengalaman belajarnya. Sementara Saracho dan Rotherham (Jiang, 2000) juga menyebutkan ciri-ciri dari konsep diri negatif, yaitu memandang dirinya rendah dan tidak mampu menggunakan pengalaman belajarnya.

Pembelajaran Kontekstual Berbantuan Geogebra; Pembelajaran kontekstual berbantuan Geogebra menyediakan lingkungan belajar yang berpusat pada siswa, dimana siswa dapat mengkonstruksi pengetahuannya melalui aktivitas bertanya, proses menemukan dari lingkungan belajarnya dan mampu mengkomunikasikan pengetahuan yang diperolehnya serta melakukan refleksi dari apa yang sudah diketahui maupun yang baru saja diketahuinya. Untuk meningkatkan interaksi, kolaborasi dan sumbangsih siswa dalam mengkonstruksi pengetahuannya berdasarkan pada pengalaman belajar mereka sendiri maka digunakanlah perangkat lunak Geogebra yang bertujuan untuk membantu meningkatkan hasil belajar siswa.

Penemuan Terdahulu yang Relevan; Beberapa hasil penelitian terdahulu mengenai keberhasilan pembelajaran dengan beberapa metode yang digunakan untuk meningkatkan kemampuan berpikir tingkat tinggi siswa menengah dalam pembelajaran matematika yang pernah dilakukan, adalah:

Anggraeni(2012), Koswara, Sumarmo dan Kusumah (2012) menyatakan bahwa kemampuan komunikasi matematik siswameningkat melalui pendekatan kontekstual dan strategi FormulateShare-Listen-Create (FSLC) serta melalui pembelajaran kontekstual berbantuan Autograph. Offirstson (2012) menyimpulkan bahwa pendekatan inquiry berbantuan program Cinderella dapat meningkatkan kemampuan pemecahan masalah.Choi (2010) mengemukakan hasil temuan yang menyatakan bahwa siswa termotivasi belajar matematika dengan menggunakan Geogebra, siswa dapat menciptakan formula mereka sendiri dan belajar menggunakan perangkat lunak tersebut serta dapat memodelkan secara matematika, juga merupakan perangkat lunak yang mudah digunakan.Yonandi (2011) menemukan bahwa kemampuan berpikir tingkat tinggi siswa meningkat setelah memperoleh pembelajaran yang inovatif.Pembelajaran yang melibatkan siswa belajar aktif dan berbantuan komputer juga membuat siswa belajar matematika lebih menyenangkan, membantu siswa memahami konsep, mencapai hasil belajar matematika yang lebih baik dari siswa yang belajar secara ekspositori.

\section{METODE PENELITIAN}

Desain Penelitian; Metode penelitian yang dilakukan adalah kuasi eksperimen. Penelitian ini bersifat kuantitatif.Desain yang digunakan adalah desain kelompok kontrol 
non-ekivalen. Desain penelitian adalah sebagai berikut:

O.... X.... O. O O

(Ruseffendi, 2010:53)

Keterangan:

$\mathrm{X}$ : Pembelajaran kontekstual berbantuanGeoGebra

$\mathrm{O}:$ Soal pretest $=$ soal postes

Populasi dan Sampel Penelitian; Penelitian ini dilakukan di satu SMP swasta di Bandung Provinsi Jawa Barat.Pelaksanaan penelitian dilakukan pada siswa kelas VIII pada tahun ajaran 2015/2016.Populasi dari penelitian ini adalah seluruh siswa kelas VIII yang ada di sekolah tersebut.Peneliti menggunakan dua kelas dari kelas VIII.Dua kelas tersebut masing- masing dijadikan kelas eksperimen dan kelas kontrol.Jumlah sampel dalam penelitian ini adalah 48 siswa yang masingmasing kelas terdiri dari 24 orang. Pemilihan kelas eksperimen dan kontrol dilakukan dengan cara kelompok (Ruseffendi, 2010:101).

Teknik Pengumpulan Data; Pengumpulan data dilakukan melalui tes dan skala konsep diri.Tes yang diberikan terdiri dari dua paket yang masing-masing digunakan untuk mengukur kemampuan pemecahan masalah dan komunikasi matematis. Sedangkan skala konsep diri matematis diberikan untuk mengukur sejauh mana siswa tersebut mengenal konsep diri mereka terhadap matematika.Tes kognitif diberikan sebelum dan sesudah seluruh pembelajaran selesai dilaksanakan dan skala konsep diri diberikan setelah seluruh pembelajaran selesai dilaksanakan di kelas eksperimen dan kelas kontrol. Pedoman penskoran untuk kemampuan pemecahan masalah matematis sesuai dengan Schoen dan Ochmke (Sumarmo, 2012), sedangkan untuk kemampuan komunikasi matematis berpedoman pada Holistic Scoring Rubrics yang dikemukakan Cai, Lane dan Jakabcsin (Elliott \& Kenney, 1996). Skala konsep diri matematis dibuat dengan menggunakan skala Likert yang bergradasi dari sangat positif sampai sangat negatif.Tes kemampuan telah terlebih dahulu melalui uji kelayakan butir soal, diantaranya adalah uji validitas, reliabilitas, daya pembeda dan tingkat kesulitan yang diujikan kepada siswa kelas IX, kemudian untuk skala konsep diri juga telah melalui uji validitas dan uji reliabilitas.

Teknik Pengolahan Data; Data yang dianalisis dalam penelitian ini adalah data kuantitatif berupa hasil kemampuan pemecahan masalah, komunikasi, dan konsep diri matematis siswa.Data pretes dan postes yang diperoleh pada setiap kemampuan diolah terlebih dahulu untuk mencari data gain ternormalisasi, hal ini dilakukan untuk melihat peningkatan skor kemampuan yang terjadi pada siswa setelah mengalami perlakuan.Untuk menguji hipotesis maka dilakukan analisis menggunakan rumus statistik kesamaan dua rerata yaitu uji-t jika data berdistribusi normal dan homogeny, atau uji-t' jika data berdistribusi normal dan tidak homogen.Uji statistik terlebih dahulu untuk menentukan normalitas data dan homogenitas varians sebagai uji prasyarat sebelum dilakukannya uji kesamaan dua rerata.Sebelum itu ditentukan rerata skor dan simpangan bakunya.

\section{HASIL PENELITIAN DAN PEMBAHASAN}

Pada skor pretes, postes dan gain ternormalisasi masing-masing dilakukan uji statistik perbedaan rerata untuk melihat apakah pada data pretes terdapat perbedaan pada kedua kelas sampel atau tidak. Kemudian pada data postes dan data gain ternormalisasi dilakukan uji statistik untuk melihat apakah kelas eskperimen memperoleh skor yang lebih baik daripada kelas ekspositori. Sebelum dilakukan uji perbedaan rerata terlebih dahulu dilakukan uji normalitas dan homogenitas sebagai prasyarat.Uji normalitas digunakan uji KolmogorovSmirnov dikarenakan data kurang dari 30 dan diperoleh data berdistribusi normal pada semua kemampuan pada kedua kelas sampel. 
Selanjutnya dilakukan uji homogenitas, jika data homogen maka dilakukan uji-t sementara jika data tidak homogen dilakukan uji-t' untuk melihat kesamaan dua rerata.Berikut disajikan hasil analisis tes kemampuan pemecahan masalah, komunikasi, dan konsep diri matematis (Tabel 1).

Tabel 1

Analisis hasil tes pemecahan masalah, komunikasi, dan konsep diri matematis

\begin{tabular}{cccc}
\hline $\begin{array}{c}\text { Kemampuan } \\
\text { Matematis }\end{array}$ & Tes & $\begin{array}{c}\text { Uji Perbedaan } \\
\text { Rerata }\end{array}$ & Kesimpulan \\
\hline \multirow{2}{*}{$\begin{array}{c}\text { Pemecahan } \\
\text { Masalah }\end{array}$} & Pretes & Uji-t’ & Terdapat perbedaan yang signifikan \\
\cline { 2 - 4 } & Postes & Uji-t & Lebih baik \\
\cline { 2 - 4 } & n-gain & Uji-t’ & Tidak lebih baik \\
\hline \multirow{3}{*}{ Komunikasi } & Pretes & Uji-t & Tidak terdapat perbedaan yang signifikan \\
\cline { 2 - 4 } & Postes & Uji-t & Tidak lebih baik \\
\cline { 2 - 4 } & n-gain & Uji-t & Tidak lebih baik \\
\hline Konsep Diri & Postes & Uji-t & Tidak terdapat perbedaan yang signifikan \\
\hline
\end{tabular}

Kemampuan Pemecahan Masalah

Matematis; Hasil analisis uji kesamaan rerata hasil pretes untuk kedua kelas menunjukkan bahwa kemampuan pemecahan masalah matematis awal kedua kelas relatif berbeda, yaitu 12,33 untuk kelas eksperimen dan 9,08 untuk kelas kontrol. Hal ini mengindikasikan siswa kedua kelas mempunyai kemampuan awal pemecahan masalah matematis yang berbeda. Skor postes menunjukkan adanya kenaikan baik itu di kelas eksperimen $(23,13)$ maupun kelas kontrol $(17,67)$. Adapun hasil uji perbedaan terhadap rerata postes dengan menggunakan uji-t menunjukkan bahwa pencapaian kelas eksperimen lebih baik dibandingkan dengan kelas kontrol. Jika dianalisis lebih mendalam, pencapaian skor postes yang lebih baik yang diperoleh oleh siswa yang memperoleh pembelajaran kontekstual berbantuan geogebra dikarenakan kemampuan awal kedua kelas sampel memang sudah berbeda satu sama lain, dimana kelas eksperimen cenderung memiliki kemampuan awal yang lebih baik daripada kelas kontrol.

Dilihat dari hasil uji perbedaan rerata n-gain menunjukkan diterimanya hipotesis penelitian yang berbunyi peningkatan kemampuan pemecahan masalah matematis siswa yang memperoleh pembelajaran kontekstual berbantuan geogebra tidak lebih baik daripada siswa yang pembelajarannya ekspositori. Perolehan skorpeningkatan untuk kelas eksperimen adalah 0,29 dan untuk kelas kontrol adalah 0,21 , yang keduanya berada pada kualifikasi rendah. Hal ini menunjukkan bahwa pembelajaran kontekstual berbantuan geogebra tidakmemberikan pengaruh yang signifikan terhadap peningkatan kemampuan pemecahan masalah matematis siswa.

Kemampuan Komunikasi Matematis; Hasil pengujian terhadap rerata skor pretes menunjukkan bahwa tidak terdapat perbedaan antara kemampuan awal komunikasi matematis siswa antara kelas eksperimen dan kelas kontrol. Rerata kemampuan awal kelas eksperimen sebesar 13,25 sedangkan rerata kemampuan awal kelas kontrol sebesar 13,5. Ini berarti kemampuan komunikasi matematis kedua kelas sebelum diberi perlakuan adalah sama.Rendahnya kemampuan awal pada kedua kelas sampel tersebut adalah wajar dikarenakan siswa belum memperoleh materi yang diujikan.

Rerata Skor postes menunjukkan adanya kenaikan kemampuan komunikasi matematis pada kedua kelas $(25,63$ pada kelas eksperimen dan 21,93 pada kelas kontrol), tetapi berdasarkan hasil uji statistic kesamaan dua rerata diperoleh bahwa pencapaian siswa yang memperoleh pembelajaran kontekstual berbantuan geogebra tidak lebih baik daripada siswa yang memperoleh pembelajaran ekspositori. Begitu pula jika dilihat dari 
perolehan rerata skor n-gain. Peningkatan kemampuan matematis kelas eksperimen berada pada kualifikasi sedang $(0,34)$, dan pada kelas kontrol pada kualifikasi rendah $(0,24)$. Pengujian rerata dengan menggunakan uji-t menunjukkan bahwa peningkatan kemampuan komunikasi matematis siswa yang memperoleh pembelajaran kontekstual berbantuan geogebra tidak lebih baik jika dibandingkan dengan siswa yang mendapatkan pembelajaran ekspositori.Hal ini menunjukkan bahwa pembelajaran kontekstual berbantuan geogebra tidakmemberikan pengaruh yang signifikan terhadap peningkatan kemampuan komunikasi matematis siswa.

Konsep Diri Matematis; Rerata skor hasil uji pencapaian konsep diri matematis siswa diperoleh 89,58 dan 92,08, yang mengindikasikan bahwa konsep diri kedua kelas sampel tidak berbeda satu sama lain.Konsep diri matematis siswa pada kedua kelas sampel berada pada kategori positif dibandingkan dengan skor netral yaitu 84.Karena data pencapaian konsep diri matematis berdistribusi normal dan variansinya homogen, maka dilakukan uji-t sebagai uji kesamaan dua rerata.Hasil uji-t yang menerima hipotesis nol berarti tidak terdapat perbedaan pencapaian konsep diri matematis antara kedua kelas sampel.Hal ini mengindikasikan bahwa pembelajaran kontekstual berbantuan geogebra tidak memberikan pengaruh yang signifikan terhadap pencapaian konsep diri matematis siswa.

Sangat dimungkinkan terjadi bahwa konsep dirimatematis siswa yangmemperoleh pembelajaran kontekstual berbantuan geogebra tidak berbeda secara signifikan terhadap konsep diri matematis siswa yang memperoleh pembelajaran ekspositori.Hal ini dikarenakan konsep diri matematis siswa tidak dapat terbentuk dalam waktu yang singkat. Untuk merubah cara pandang yang telah melekat pada siswa tidaklah mudah, apalagi penelitian ini hanya berlangsung selama 12 kali pertemuan. Menurut Suherman (Rahmatudin, 2013) pembentukan daerah afektif sebagai hasil belajar relatif lebih lambat daripada pembentukan daerah kognitif dan psikomotorik, karena perubahan daerah afektif memerlukan waktu yang lebih lama dan merupakan akibat dari pembentukan pada daerah kognitif dan psikomotorik.

\section{SIMPULAN}

a. Pencapaian kemampuan pemecahan masalah matematis siswa yang memperoleh pembelajaran kontekstual berbantuan geogebra lebih baik dibandingkan dengan siswa yang memperoleh pembelajaran ekspositori.

b. Pencapaian kemampuan komunikasi matematis siswa yang memperoleh pembelajaran kontekstual berbantuan geogebra tidak lebih baik dibandingkan dengan siswa yang memperoleh pembelajaran ekspositori.

c. Peningkatan kemampuan pemecahan masalah matematis siswa yang memperoleh pembelajaran kontekstual berbantuan geogebra tidak lebih baik daripada siswa yang pembelajarannya ekspositori.

d. Peningkatan kemampuan komunikasi matematis siswa yang memperoleh pembelajaran kontekstual berbantuan geogebra tidak lebih baik daripada siswa yang pembelajarannya ekspositori.

e. Tidak terdapat perbedaan yang signifikan pada pencapaian konsep diri matematis siswa pada kedua kelas sampel. 


\section{DAFTAR RUJUKAN}

Anggraeni, D. (2012). Meningkatkan kemampuan pemahaman dan komunikasi matematik siswa SMK melalui pendekatan Kontekstual dan strategi Formulate-Share-Listen-Create (FSLC).Tesis SPs UPI. Bandung: Tidak diterbitkan.

Choi, K. S. (2010). Motivating students in learning mathematics with Geogebra.Annals.Computer Science Series.8. 2. 65-76.

Departemen Pendidikan Nasional RI. (2006). Permendiknas No.22 tentang standar untuk satuan pendidikan dasar dan menengah. Jakarta: Depdiknas RI.

Elliot, P.C., Kenney, M.J. (1996). Communication in mathematics, K-12 and beyond. Virginia: NCTM.

Githua, B. N., \& Mwangi, J. G. (2003).Students' mathematics self-concept and motivation to learn mathematics: relationship and gender differences among Kenya's secondary-school students in Nairobi and Rift Valley provinces. International Juournal of Educational Development.23, -, 487-499.

Jiang, X. (2000).A case study of high and low levels of self-concept in children. Collected papers of the inaugural self-concept Enhancement and Learning Facilitation (SELF) Research Centre International Conference, Sydney, Australia, October 5-6.282-291.

Koswara, U., et.al. (2012). Mathematical reasoning and communication abilities: experiment with grade-10 students by using Contextual teaching assisted with Autograph program. Educationist, Jurnal Kajian, Filosofi, Teori, Kualitas, dan Manajemen Pendidikan.VII, 2, 125-131.

Lindawati, S. (2010).Pembelajaran matematika dengan pendekatan inkuiri terbimbing untuk meningkatkan kemampuan pemahaman dan komunikasi matematis siswa sekolah menengah pertama. Tesis SPs UPI. Bandung: Tidak diterbitkan.

Multahadah, C. (2015). Penerapan teknik Metacognitive Scaffolding dengan pendekatan Saintifik untuk meningkatkan kemampuan pemecahan masalah matematis dan motivasi berprestasi siswa SMA.Tesis SPs UPI. Bandung: Tidak diterbitkan.

Offirstson, T. (2012).Inquiry approach with Cinderella software for improving students ' mathematical reasoning and problem solving abilities. Tesis SPs UPI. Bandung: Tidak diterbitkan.

Polya, G. (1957). How to solve it. New York: Doubleday \& Company, Inc.

Rahmatudin, J. (2013). Penerapan model pembelajaran Search, Solve, Create, and Share untuk meningkatkan kemampuan penalaran matematis dan self concept siswa SMP negeri 1 Kedawung.Tesis SPs UPI. Bandung: Tidak diterbitkan.

Ruseffendi, E.T. (2006). Pengantar kepada membantu guru mengembangkan kompetensinya dalam pengajaran matematika untuk meningkatkan CBSA. Bandung: Tarsito.

Ruseffendi, E.T. (2010). Dasar-dasar penelitian pendidikan \& bidang non-eksakta lainnya. Bandung: Tarsito.

Sumarmo, U. (2012). Proses berpikir matematik: apa dan mengapa dikembangkan. Bahan belajar mata kuliah Proses Berpikir Matematik program S2 pendidikan matematika STKIP Siliwangi. Bandung.

Trends in International Mathematics and Science Study [TIMSS].(2011). Contextual Framework Chapter 3.TIMSS.

Yonandi.(2011). Meningkatkan kemampuan komunikasi dan pemecahan masalah matematika melalui pembelajaran Kontekstual berbantuan komputer pada siswa sekolah menengah atas. Disertasi SPs UPI. Bandung: Tidak diterbitkan. 